\title{
TRANSFORMACIÓN DE TOMATE CON GENES INVOLUCRADOS EN INMUNIDAD VEGETAL PARA CONFERIR RESISTENCIA AMPLIA CONTRA BACTERIAS
}

\author{
TOMATO TRANSFORMATION WITH GENES INVOLVED IN PLANT \\ IMMUNITY TO CONFER BROAD RESISTANCE AGAINST BACTERIA
}

\author{
Marco M. Plancarte-De la Torre¹, Héctor G. Núñez-Palenius² and Miguel A. Gómez-Lim
}

\begin{abstract}
'Departamento de Ingeniería Genética, Centro de Investigación y de Estudios Avanzados. Km. 9.6 Libramiento Norte Carr. Irapuato-León 368211. Irapuato, Gto. México. Tel 01 (462) 623-9600 Ext. 401. ²Campus Irapuato-Salamanca, División de Ciencias de la Vida, Universidad de Guanajuato. Exhacienda El Copal s/n. 36500, Apartado Postal 311, Irapuato, Gto. Tel 01 (462) 624-1889.
\end{abstract}

*Autor para correspondencia (mgomez@ira.cinvestav.mx)

\section{RESUMEN}

Las enfermedades de las plantas exacerban el actual déficit de suministro de alimentos. Para defenderse contra infecciones, las plantas responden a moléculas básicas y características de los patógenos llamadas patrones moleculares asociados a patógenos (PAMPs, por sus siglas en inglés), lo que activa respuestas de inmunidad basal conocidas como inmunidad activada por PAMP (PTI, por sus siglas en inglés). Se sabe que la actividad de algunos receptores de reconocimiento de PAMPs se mantiene después de su transferencia entre familias vegetales. El objetivo de este trabajo fue transferir de manera conjunta los genes EFR, FLS2 y BAK1, involucrados en el reconocimiento de PAMPs y en la activación de la PTI en Arabidopsis, a plantas de tomate (Solanum lycopersicum L.), con el fin de generar una resistencia de amplio espectro contra patógenos bacterianos. Para lograrlo se siguió una estrategia basada en la transformación genética de plantas vía Agrobacterium tumefaciens, con un casete de locus sencillo conformado por los genes antes mencionados, retando posteriormente a las plantas transgénicas con bacterias patógenas. Se logró producir plantas de tomate $\mathrm{F}_{4}$ que mostraron un aumento de resistencia a las bacterias en comparación con plantas silvestres; sin embargo, se desconoce la contribución que tuvo cada uno de los genes. Una línea en particular mostró una reducción de cerca de 60,73 y $83 \%$ de la infección bacteriana cuando fue infectada con Pseudomonas syringae pv. syringae, Pseudomonas syringae pv. tomato y Clavibacter michiganensis subsp. michiganensis, respectivamente. Los resultados sugieren que la expresión heteróloga de múltiples genes involucrados en la PTI bajo el control de un solo promotor puede ser usada para diseñar una resistencia de amplio espectro a patógenos bacterianos en cultivos importantes.

Palabras clave: Solanum lycopersicum, inmunidad activada por PAMP, PAMPs, resistencia transgénica.

\section{SUMMARY}

Plant diseases exacerbate the current deficit of food supply. To defend themselves against infections, plants respond to basic characteristic pathogen molecules called pathogen associated molecular patterns (PAMPs), which activate basal immunity responses known as PAMP triggered immunity (PTI). It is known that the activity of some PAMPs recognition receptors is retained after their transfer between plant families. The objective of this work was to jointly transfer the genes EFR, FLS2 and BAK1, involved in recognition of PAMPs and activation of PTI in Arabidopsis, into tomato (Solanum lycopersicum L.) plants, with the goal of generating a wide-range resistance against bacterial pathogens. To reach that, a strategy based in the genetic transformation of plants with a single locus cassette containing the aforementioned genes via Agrobacterium tumefaciens was followed with the posterior challenge of the transgenic plants with pathogenic bacteria. It was possible to produce transgenic $\mathrm{F}_{4}$ tomato plants that showed increased resistance to bacteria compared with wild type plants, however the contribution that each of the genes had is unknown. One line in particular showed a reduction of near 60,73 and $83 \%$ of bacterial infection when infected with Pseudomonas syringae pv. syringae, Pseudomonas syringae pv. tomato and Clavibacter michiganensis subsp. michiganensis respectively. Results suggest that the heterologous expression of multiple PTI-involved genes under the control of a single promoter could be used to engineer broadspectrum disease resistance to bacterial pathogens in important crops.

Index words: Solanum lycopersicum, PAMP trigger immunity, PAMPs, transgenic resistance.

\section{INTRODUCTION}

The economic impact of bacterial diseases in crops can be large. The genus Pseudomonas comprises gram-negative plant pathogenic species, with $P$. syringae being the most economically important with more than 50 pathovars (Höfte and De Vos, 2006). The bacterial genus Clavibacter consists of only one species $C$. michiganensis which is a gram-positive phytopathogen and is subdivided into five subspecies, according to their host specificity. Both genera include important tomato pathogens: P. syringae pv. syringae, P. syringae pv. tomato and C. michiganensis subsp. michiganensis (Eichenlaub et al., 2006).

In the field, to combat bacteria there is no alternative other than the application of pesticides, so it remains as the principal available method for control of pathogens. This has significantly increased the concentration of pesticides in food and in our environment, with associated negative effects on human health (Tago et al., 2014). It is then clear that more sustainable methods are required to fight plant diseases. Recent advances in genomics and molecular genetics of host resistance and pathogenesis give hope of novel solutions to many important crop diseases (Wulff et al., 2011). 
Plants possess a well-adapted innate immune system consisting of two perception systems: PAMP-triggered immunity (PTI) and effector-triggered immunity (ETI) (Walters, 2015). In PTI, cell surface-located receptors, called patternrecognition receptors (PRR), detect conserved pathogenassociated molecular patterns (PAMP), which act as a signature of a whole class of microbes. Pathogens have evolved mechanisms to evade PTI and deliver proteins, called effectors, directly into the cell (Boller and Felix, 2009). These effectors are mostly species-specific and promote virulence leading to effector triggered susceptibility (ETS). If the plant recognizes the effector, ETI is then activated. It mostly acts inside the cell, using the nucleotide-binding leucine-rich repeat (NB-LRR) protein products encoded by resistance $(R)$ genes (Walters, 2015). ETI is race-specific and rarely confers broad-spectrum disease resistance. Moreover, it is often rapidly overcome by evolving pathogens that lose or mutate the nonessential recognized effector or that produce new effectors to counteract ETI (Lacombe et al., 2010). When PRRs detect PAMPs a cascade of signaling pathways is triggered, which cause activation of defense mechanisms and ultimately leads to either resistance or cell death.

One of the best-characterized PRRs is the receptor-like kinase (RLK) FLAGELLIN-SENSING 2 (FLS2). The Arabidopsis FLS2 (AtFLS2) receptor recognizes the highly conserved 22-amino-acid epitope (flg22) of the flagellin protein. For an effective activation of the PTI outputs, FLS2 has to interact with co-receptors which are members of the somatic embryogenesis-related kinase (SERK) family, mainly BRI1-ASSOCIATED RECEPTOR KINASE1 (BAK1) and BAK1LIKE 1 (BKK1) (Sun et al., 2013). Another well described PRR is the RLK EF-Tu RECEPTOR (EFR), which recognizes the bacterial elongation factor EF-Tu. The receptor detects the $\mathrm{N}$-acetylated peptide comprising the first 18 aminoacids of EF-Tu, termed elf18. Perception of elf18 triggers an oxidative burst, callose deposition, seedling growth inhibition and defense gene expression ultimately leading to resistance to infection with pathogenic bacteria (Kunze et al., 2004). Just like FLS2, EFR is dependent on co-receptor BAK1 to trigger PTI outputs.

BAK1 (also called SERK3), is a LRR-RLK of the SERK family. It positively regulates brassinosteroid (BR) responses, such as cell elongation and division, by forming a ligand-dependent complex with the BR receptor BRI1 ( $\mathrm{He}$ et al., 2013). BAK1 also plays a role in plant PTI, working as co-receptor for FLS2, EFR and other PRRs (Chinchilla et al., 2009). Recent results have demonstrated the biotechnological potential of PRRs in providing enhanced immunity. Many major resistance genes have now been shown to retain function when transferred between species. The EFR pattern-recognition receptor, present only in Brassica- ceae, functions to provide bacterial disease control in Solanaceae (Lacombe et al., 2010; Wulff et al., 2011; Zipfel et al., 2006).

The deployment of several genes within a single variety is known as pyramiding (Kumar and Nayak, 2010). In theory the likelihood of a pathogen evolving to overcome a gene pyramid is reduced in proportion to the number of its component resistance genes (Fukuoka et al., 2009). Based on the above, tomato plants (Solanaceae) were transformed with a cassette constituted by a pyramid of three Arabidopsis thaliana genes related to PTI (AtEFR, AtFLS2 and At$B A K 1$ ), in order to provide the plants with a broad-spectrum resistance against bacteria. It was hypothesized that plants expressing multiple PAMPs recognition receptors (PRRs) will show resistance to a wide range of bacteria, and that this resistance will be hard to overcome by pathogens, and therefore, more durable.

\section{MATERIALS AND METHODS}

The EFR, FLS2 and BAK1 genes were amplified by PCR from a CDNA library of $A$. thaliana ecotype 'Columbia' using the primers (EFR: 5'-ATCGGGTACCATGAAGCTGTCCTTTTCACTTG-3' and 5'-ATCGGCATGCCATAGTATGCATGTCCGTATTTAAC-3'; FLS2: 5'-ACTGGTCGACATGAAGTTACTCTCAAAGAC-3' and 5'-ATCGGGATCCAACTTCTCGATCCTCGTTACG-3'; BAK1: 5'-ACTGTCTAGAATGGAACGAAGATTAATGATC-3' and 5'-ATCGCTCGAGTCTTGGACCCGAGGGGTATTC-3'), where underlined bases indicate restriction sites added for gene subcloning. The AtEFR, AtBAK1 and AtFLS2 genes were linked in that order using endonuclease restriction and ligase enzymes. Genes were separated from each other by an ubiquitin monomer from tobacco. The final cassette composed by the three genes was cloned into the plant expression vector $p C A M B I A$ 2301. This vector has the Cauliflower Mosaic Virus $35 S$ promoter, in addition to $\beta$-glucuronidase (GUS) and the kanamycin resistance genes.

Plasmid pCAMBIA-EFR:Ub:BAK1:Ub:FLS2 containing the PRRs genes cassette was transferred into Agrobacterium tumefaciens strain-LBA4404 by electroporation. Transgenic tomato (S. lycopersicum) variety TA234 plants expressing $P C A M B I A-E F R: U b: B A K 1: U b: F L S 2$ was generated by the routine method used in the laboratory as described by Peña-Ramírez et al. (2007). Several primary transformants were recovered after selection on kanamycin-containing plant plates. After transfer to soil, the kanamycin resistant plants were tested for GUS activity, resulting in four positive plants, which were grown in the greenhouse and allowed them to self-pollinate to get $F_{1}$ to $F_{4}$ generations. GUS assays were performed on plants from each generation. 
Genomic DNA was extracted from young leaves of GUS positive plants from each generation using Plant DNAzol ${ }^{\mathrm{TM}}$ reagent (Invitrogen ${ }^{T M}$ ). PCR was performed on those DNAs using the same set of primers employed to amplify the AtEFR, AtBAK 1 and AtFLS2 genes from the A. thaliana cDNA library.

Total RNA was extracted from young leaves of each plant generation using PureLink ${ }^{\circledR}$ Plant RNA Reagent (Thermo Fisher Scientific, Waltham, Massachusetts, USA), and CDNA was synthesized from the RNA using SuperScript ${ }^{\circledR}$ III Reverse Transcriptase (Invitrogen ${ }^{T M}$ ). Reverse transcription PCR (RT-PCR) was performed on the CDNA using the primers (EFR: 5'-GGCGATTATAACCTCCACAG-3' and 5'-TACTGCTTCATCCGTTCTC A-3'; FLS2: 5'-ACGCCTCTGATCTAATGGG-3' and 5'-GGATGACTCTGGTTCTCTTCG-3'; BAK1: 5'-TGACGCTACAAGTTCTGGAT-3' and 5'-ATGGCGGTGTAGGAGAGATA-3'; EF-a 5'-TACTGG TGGTTTTGAAGCTG-3' and 5'-AACTTCCTTCACGATTTCATCATA-3').

For the bacterial challenge tests $S$. lycopersicum variety TA234 was grown from the transgenic lines generated as one plant per pot at $22{ }^{\circ} \mathrm{C}$ under a $16 \mathrm{~h}$ photoperiod. Pseudomonas syringae pv. syringae B728a and Pseudomonas syringae pv. tomato DC3000 were grown in a liquid mannitol glutamate (MG) medium (10 $\mathrm{g} \mathrm{L}^{-1}$ mannitol, $2 \mathrm{~g} \mathrm{~L}^{-1}$ L-glutamic acid, $0.5 \mathrm{~g} \mathrm{~L}^{-1} \mathrm{KH}_{2} \mathrm{PO}_{4^{\prime}} 0.2 \mathrm{~g} \mathrm{~L}^{-1} \mathrm{NaCl}, 0.2 \mathrm{~g} \mathrm{~L}^{-1}$ $\left.\mathrm{MgSO}_{4} \cdot 7 \mathrm{H}_{2} \mathrm{O}, \mathrm{pH} 7.0\right)$ at $28^{\circ} \mathrm{C}$. Bacterial suspensions were prepared as previously described by Katagiri et al. (2002), and were adjusted to $1 \times 10^{5}$ colony-forming units (CFU) $\mathrm{mL}^{-1}\left(\mathrm{OD}_{600}=0.0002\right)$ in sterile phosphate (PBS) buffer (137 $\mathrm{mM} \mathrm{NaCl}, 2.7 \mathrm{mM} \mathrm{KCl}, 10 \mathrm{mM} \mathrm{Na}_{2} \mathrm{HPO}_{4^{\prime}} 2 \mathrm{mM} \mathrm{KH}_{2} \mathrm{PO}_{4^{\prime}} \mathrm{pH}$ 7.4).

Three-week-old tomato plants with three to four true leaves were used for inoculation. Bacterial suspensions were infiltrated with a needleless hypodermic syringe into the leaves. As a control, plants were mock inoculated in the same way with PBS. Bacterial growth was monitored within leaf tissue by grinding six leaf disks $\left(0.6 \mathrm{~cm}^{2}\right)$ per sample and plating dilutions of the ground material on King's $B(\mathrm{~KB})$ medium (20 g L-1 peptone, $1.5 \mathrm{~g} \mathrm{~L}^{-1} \mathrm{MgSO}_{4} \cdot 7 \mathrm{H}_{2} \mathrm{O}, 1.5 \mathrm{~g} \mathrm{~L}^{-1}$ $\mathrm{K}_{2} \mathrm{HPO}_{4}, 15 \mathrm{~mL} \mathrm{~L}^{-1}$ glycerin, $\mathrm{pH} 7.2$ ) with $25 \mu \mathrm{g} \mathrm{mL}^{-1}$ nalidixic acid at $28^{\circ} \mathrm{C}$. Three replicated samples were taken every other day over a $10 \mathrm{~d}$ period. Each experiment was independently conducted three times within each plant generation.

For Clavibacter michiganensis subsp. michiganensis, bacterial cultures were prepared and inoculations were performed as described by Louws et al. (1998). Briefly, $\mathrm{Cmm}$ was grown in liquid nutrient broth yeast extract (NBY) medium (8 $\mathrm{g} \mathrm{L}^{-1}$ nutrient broth, $2 \mathrm{~g} \mathrm{~L}^{-1}$ yeast extract, $2 \mathrm{~g} \mathrm{~L}^{-1}$
$\mathrm{K}_{2} \mathrm{HPO}_{4}, 0.5 \mathrm{~g} \mathrm{~L}^{-1} \mathrm{KH}_{2} \mathrm{PO}_{4}, 5 \mathrm{~g} \mathrm{~L}^{-1}$ glucose, $\mathrm{pH} 7.0$ ) at $28{ }^{\circ} \mathrm{C}$ Bacteria were suspended into sterile PBS buffer and adjusted to $2 \times 10^{8} \mathrm{CFU} \mathrm{mL-1}\left(\mathrm{OD}_{600}=0.16\right)$. Three week old tomato plants with three to four true leaves were used for inoculation. For inoculation, a scalpel dipped in inoculum was used to make a tiny wound on the stem of the plant, between the cotyledons. As a control, plants were mock inoculated in the same way with sterile PBS.

Every $5 \mathrm{~d}$, from day 20 to day 40, a $1 \mathrm{~cm}$ segment of the stem $10 \mathrm{~cm}$ above the inoculation site was removed. Each stem segment was weighed and crushed in two volumes of PBS buffer. The resulting suspensions were subjected to a 10 fold serial dilution, and $0.1 \mathrm{~mL}$ aliquots were spread on agar plates containing NBY media. The number of CFU was determined after five $d$ of incubation at $28{ }^{\circ} \mathrm{C}$. Three replicate samples were taken and the experiment was conducted three times within each plant generation.

A Student $t$ test was performed taking into account the number of CFU formed by the bacterial pathogens tested on each transgenic line at the different days of measurement.

\section{RESULTS AND DISCUSSION}

Several publications report that for bacterial diseases such as blight, a broad spectrum and higher resistance can be achieved by pyramiding more than two bacterial resistance genes into one line, compared with lines with a single resistance gene (Kim et al., 2009; Suh et al., 2009). An increasing attention has focused on the accumulation of major disease resistance genes in crop plants, although it is very difficult to pyramid genes using conventional breeding methods due to the dominance and epistasis effects of genes governing disease resistance (Suh et al., 2013). For that reason, a genetic engineering approach was chosen to pyramid the genes. To pyramid all three PRRs genes into one breeding line, the pCAMBIA-EFR:Ub:BAK1:Ub:FLS2 plasmid was constructed (Figure 1). The identity of the cassette was verified by restriction mapping and sequencing.

It is important to note that although there are previous reports of plants transformed with a PRR gene (Chinchilla et al., 2006; Lacombe et al., 2010), this is the first time that plants are transformed using a multigene cassette that includes two PRRs genes (AtEFR and AtFLS2) in addition to the BAK1 co-receptor gene (AtBAK1). This could have two advantages. On the one hand it could generate resistance to a broader spectrum of pathogenic species, including both gram-negative and gram-positive bacteria. And on the other hand the resistance generated could be stronger and more durable, but to be able to assert that it would be necessary to perform more assays to determine the contribution of the 


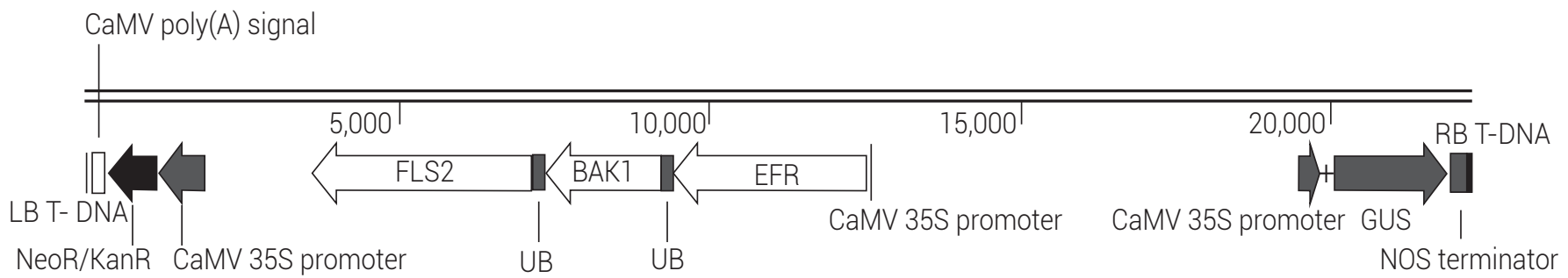

Figure 1. T-DNA region of the PCAMBIA-EFR:Ub:BAK1:Ub:FLS2 plasmid. The PRRs genes cassette was cloned into the plant expression vector $P C A M B I A$ 2301. LB T-DNA: left border from nopaline C58 T-DNA; CaMV poly(A) signal: cauliflower mosaic virus polyadenylation signal; NeoR/KanR: aminoglycoside phosphotransferase gene from Tn5; CaMV 35S promoter: cauliflower mosaic virus 35S promoter; FLS2: FLAGELLIN-SENSING 2 gene from $A$. thaliana; UB: ubiquitin monomer; BAK1: BRI1-ASSOCIATED RECEPTOR KINASE gene from $A$. thaliana; EFR: EF-Tu RECEPTOR gene from $A$. thaliana; GUS: $\beta$-glucuronidase gene; NOS terminator: nopaline synthase terminator; RB T-DNA: right border from nopaline C58 T-DNA.

pyramiding effect on the resistance. It is a well-known fact that when the resistance of a plant to a certain pathogen relies on a single gene, it is rapidly overcome by the pathogen by selecting for mutants, recombinants, or immigrants that are better adapted to the resistant variety (Brown et al., 1997; Kumar and Nayak, 2010).

Tomato transformation is a well standardized routine procedure practiced in laboratory (Peña-Ramírez et al., 2007), and for the present study four evidences were used to verify the transgenic nature of the plants: GUS expression colorimetric assays, transgenes detection by PCR amplification using specific primers, detection of transcript levels of the transgenes by RT-PCR, and resistance against phytopathogenic bacterial infections as a result of the transgenes expression. It was possible to generate several transgenic tomato lines and four of these were selected that showed GUS activity in all the tissues analyzed (leaves and fruits) (Figure 2A).

DNA was extracted from the four tomato lines and PCR was performed to determine whether the genes (AtEFR, At$B A K 1$ and AtFLS2) were present (Figure 2B). EFR gene amplified in the transgenic lines but not in the wild-type (WT) plants. This outcome was expected since tomato plants do not have an orthologue for such gene. However, FLS2 and BAK1 genes amplified not only in the transgenic lines but also in the WT, indicating that the tomato orthologues for those genes are similar enough to that from Arabidopsis, so they might be amplified using the same set of primers. The four tomato lines were allowed to self-pollinate to originate $F_{1}$ to $F_{4}$ generations. Within each generation GUS assays and PCR amplification of the genes were performed. Each consecutive generation showed an increasing percentage of positive GUS assays ( $85 \%$ for $F_{1}, 91 \%$ for $F_{2}, 94 \%$ for $F_{3}$ and $97 \%$ for $\mathrm{F}_{4}$ ), which indicates that the transgenes were integrated into the plant genome and stably inherited, and that the tomato lines were trending towards homozygosity.
Plants were transformed with a single multi-cassette vector where the three genes were separated from each other by an ubiquitin monomer linker from tobacco and under the control of a common $35 \mathrm{~S}$ promoter because this approach confers many advantages. First, the use of one promoter allows the coordinated and possible equimolar expression of the different proteins (Walker and Vierstra, 2007). Second, ubiquitin is rapidly and accurately processed in vivo by deubiquitinating enzymes, which release the attached proteins in free functional forms (Wilkinson, 2000). Third, this approach reduces the possibility of silencing the transgenes by using a single promoter, which might be a problem if more than one promoter is employed (Baulcombe, 2005).

It is important to notice that although PTI appears to be conserved across the plant kingdom, despite many similarities there are differences in the nature of $\mathrm{PTI}$ responses among different plant species (Nguyen et al., 2010). That is why it is feasible that transferring PRRs between plant families can confer new resistance capabilities against bacteria. In fact, it has already been proved that major resistance genes retain function when transferred between species. For example, the expression of EFR in the wild tobacco species Nicotiana benthamiana, that is normally unresponsive to EF-Tu, resulted in recognition of elf18 and activation of typical basal defenses (Zipfel et al., 2006). Furthermore, transgenic Solanaceae plants expressing EFR showed significant resistance to multiple gram-positive bacterial pathogens (Lacombe et al., 2010).

Flagellin, the building block of the eubacterial flagellum, is recognized by its cognate receptor FLS2 in nearly all plant species, but the recognized domain within flagellin is not necessarily the same for all plant species. For instance, members of both the Brassicaceae and Solanaceae families perceive flagellin; however, they vary in their sensitivity to different peptides of the protein (Robatzek et al., 2007). 


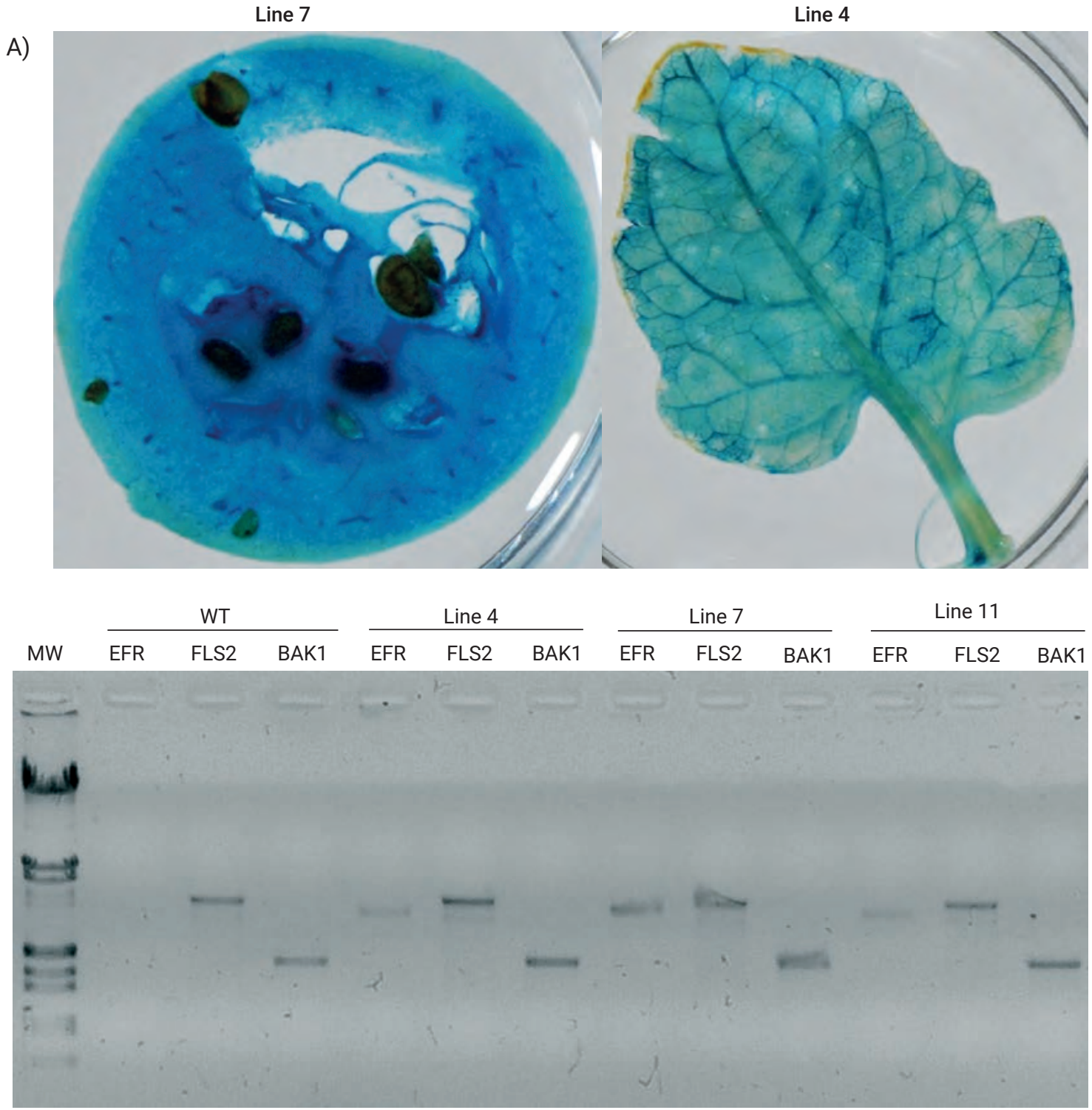

Figure 2. Molecular and histochemical evidence of the tomato transformation. (A) Stable GUS expression of $\mathrm{F}_{4}$ transgenic plants in fruit and leaf. (B) PCR of $\mathrm{F}_{4}$ transgenic and wild type (WT) plants with AtEFR, AtFLS2 and AtBAK1 primers. MW: Lambda DNA EcoRI/HindIII double digest as marker; EFR: 3,093 bp; FLS2: 3,519 bp; BAK1: 1,845 bp.

FLS2 receptors have been isolated from tomato, tobacco, and rice (Robatzek et al., 2007); all of these receptors display high levels of identity to Arabidopsis FLS2 at the amino acid level and also mediate flagellin perception; however, computational and phylogenetic approaches have sugges ted different amino acid residues as important for ligand binding (Albert et al., 2010; Boller and Felix, 2009). Considering the aforementioned, it was decided to express the AtFLS2 in tomato expecting that it would confer the tomato plants an extra flagellin epitope recognition site.

Challenging transgenic plants with phytopathogenic bacteria is the established method for testing the resistance or susceptibility of a given plant genotype to a specific pathovar (Zhao et al., 2003). It was decided to challenge plants with PSs, Pst and Cmm since they are important pathogens of tomato and the three of them are well characterized in the laboratory; more bacterial species and pathovars will be tested as they are available.

As expected, some of the transgenic lines showed resistance against the bacterial infections, even when the inoculum used for the challenges contained a much higher bacterial concentration than the one that can occur under natural infection. Line 7 in particular showed a reduction of near 60 and $73 \%$ on colony forming units (CFU) when 
infected with PSs and Pst respectively compared with the WT plants by $10 \mathrm{~d}$ post-infection (dpi) (Figure 3A). Such differences in the number of CFU were also reflected in the general appearance of the plants since disease symptoms in plants from Line 7 were much less severe than those in WT plants (Figure 3B). Tomato is normally susceptible to infections by Pst since several isolates of the bacterium display amino acid polymorphisms within flagellins that mask their recognition in tomato (Cai et al., 2011).

Previous studies had shown that AtFLS2 expression in tomato is sufficient to transfer the Arabidopsis flagellin perception system (Chinchilla et al., 2006), this is important since some studies have suggested that AtFLS2 has a broader recognition capacity than initially anticipated. For example, Ax21-derived peptides from Xanthomonas oryzae pv. oryzae activate FLS2-mediated Arabidopsis immunity, even when rice FLS2 does not appear to sense Ax21 or Ax21-derived peptides; that is, rice plants (Oryza sativa L.) lacking receptor XA21 (that still carry OsFLS2) do not respond to Ax21-derived peptides with measurable resistance (Danna et al., 2011). That may be a possible explanation to the observed resistance of the transgenic tomato lines against Pseudomonas in the present study, that heterologous expression of AtFLS2 activates plant immunity by recognition of another PAMP from Pseudomonas rather than flg22.

Additional evidence that supports these results is that Arabidopsis fls2 mutants have showed enhanced susceptibility to Pst DC3000 (Zipfel et al., 2006), demonstrating that AtFLS2 somehow perceives a PAMP from Pst activating the plant immunity. We hypothesize that for the resistance to Pseudomonas shown by the transgenic tomato plants in the present study, the contribution of AtFLS2 expression was more important than that from the expression of AtEFR, since it has already been reported that flagellin from $P$. syringae is more active triggering FLS-mediated PTI in Arabidopsis than flagellin from Agrobacterium tumefaciens or Sinorhizobium meliloti (Felix et al., 1999). Furthermore, EF-Tu from Pst DC3000 is much less active in eliciting PTI in Arabidopsis than EF-Tu from Agrobacterium (Kunze et al., 2004).

However, to be certain of this more studies and experiments are needed. It is important to notice that although the transgenic plants showed a reduced level of bacterial growth and disease symptoms, there was still a small but detectable degree of infection even in Line 7 which showed the best results. This indicates that the resistance conferred was not absolute and a possible explanation for this could be the presence of the AvrPto/AvrPtoB effectors in Pst DC3000, which are known to be strong suppressors of PTI (He et al., 2006).
In fact, it has been demonstrated that when delivered by Pst at natural levels, AvrPto and AvrPtoB target BAK1 and block the ligand-induced formation of PAMP-receptor complexes, thereby effectively impeding multiple PAMPsignaling initiation (Shan et al., 2008). Therefore, transforming tomato plants with an AtBAK1 gene, even when tomato contains an endogenous orthologue (Peng and Kaloshian, 2014), might results in overexpression of the BAK1 RLK which could probably counteract the attack of the AvrPto/AvrPtoB effectors and make the formation of PAMP-receptor complexes possible even in the presence of such effectors.

For the infections with $\mathrm{Cmm}$ the same pattern was observed despite using a much more concentrated inoculum than that a plant could encounter in nature, with some transgenic lines showing some resistance to the bacterium. Once again, the best results were found in plants from Line 7 which had a reduction of near $83 \%$ on the CFU of $\mathrm{Cmm}$ compared with the WT tomato plants by $40 \mathrm{~d}$ postinfection (Figure 4A). The decrease in the number of CFU was also reflected on the general appearance of the plants, especially in Line 7 where the bacterial canker symptoms were much milder than those of WT plants (Figure 4B). Since Clavibacter is characterized by non-motility and therefore with no flagellar structures, it is tempting to hypothesize that the resistance shown by the transgenic tomato lines in the present study was not due to the heterologous expression of the AtFLS2, but rather to the expression of the AtEFR; but once again, more trials and experiments would be needed to confirm this.

The PAMP recognized by the EFR receptor is the prokaryotic translation factor EF-Tu, the most abundant and one of the most conserved proteins in bacterial cells (Walters, 2015). Nevertheless, perception of the bacterial EF-Tu is found only in the Brassicaceae, all plants outside this family tested so far, including some Solanaceae, have failed to show the characteristic reactive oxygen species burst when challenged with the EF-Tu or its fully active elicitor peptide (elf18) (Zipfel et al., 2006). That means that expressing the EFR receptor in a Solanaceae (such as tomato in this case), confers the plant a novel tool for recognizing potential pathogens and triggering its basal immunity to fight them, as has been previously demonstrated by Lacombe et al. (2010).

In order to find an explanation to the difference on the resistance levels shown by the different transgenic lines, cDNA was synthetized from total RNA extracted from young leaves, and RT-PCR was performed on the cDNA to identify the transcript accumulation levels of the transgenes (Figure 5). Although transcript accumulation from FLS2 and BAK 1 was detectable in the WT plants (because of tomato orthologues 
A)
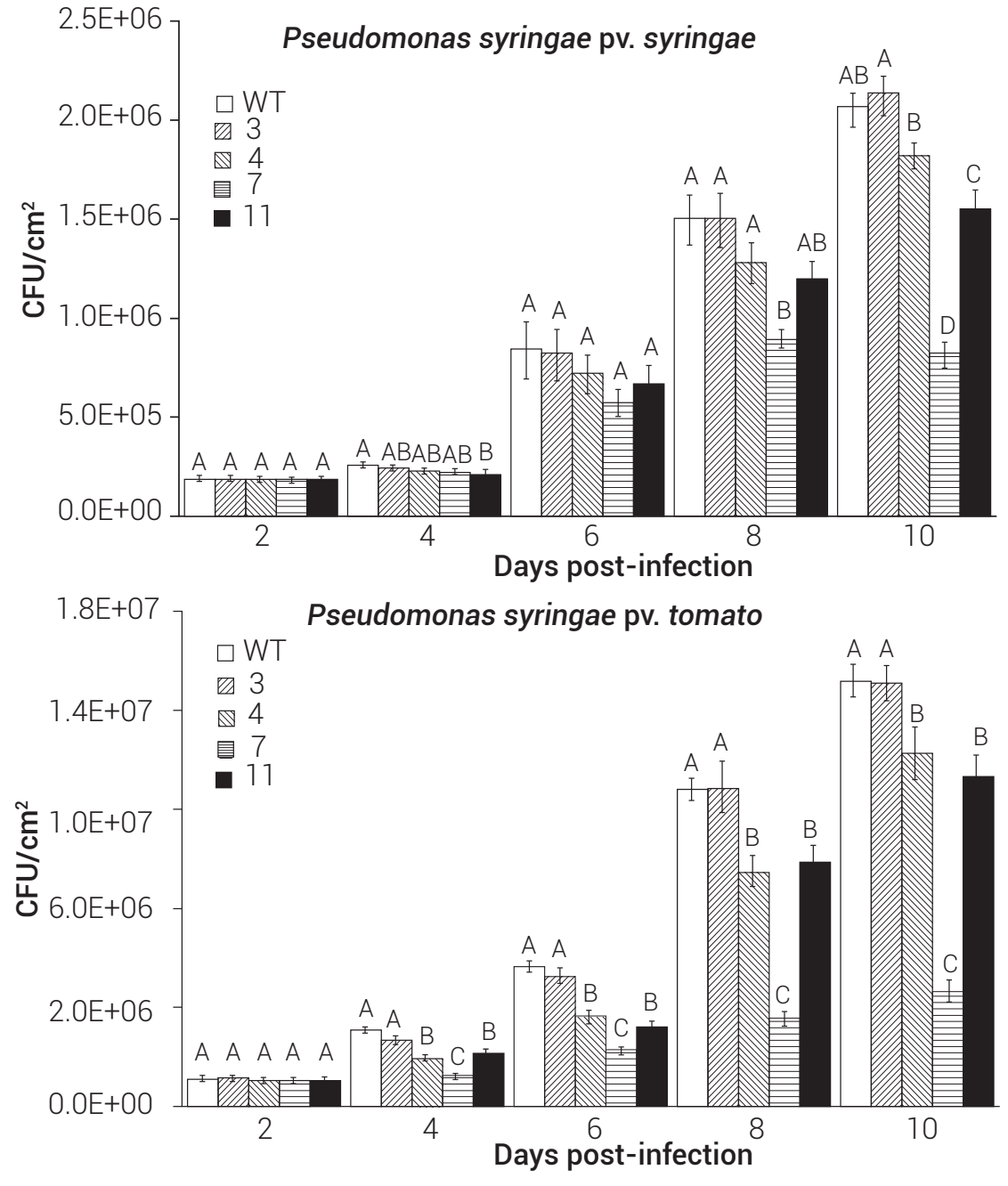

B)
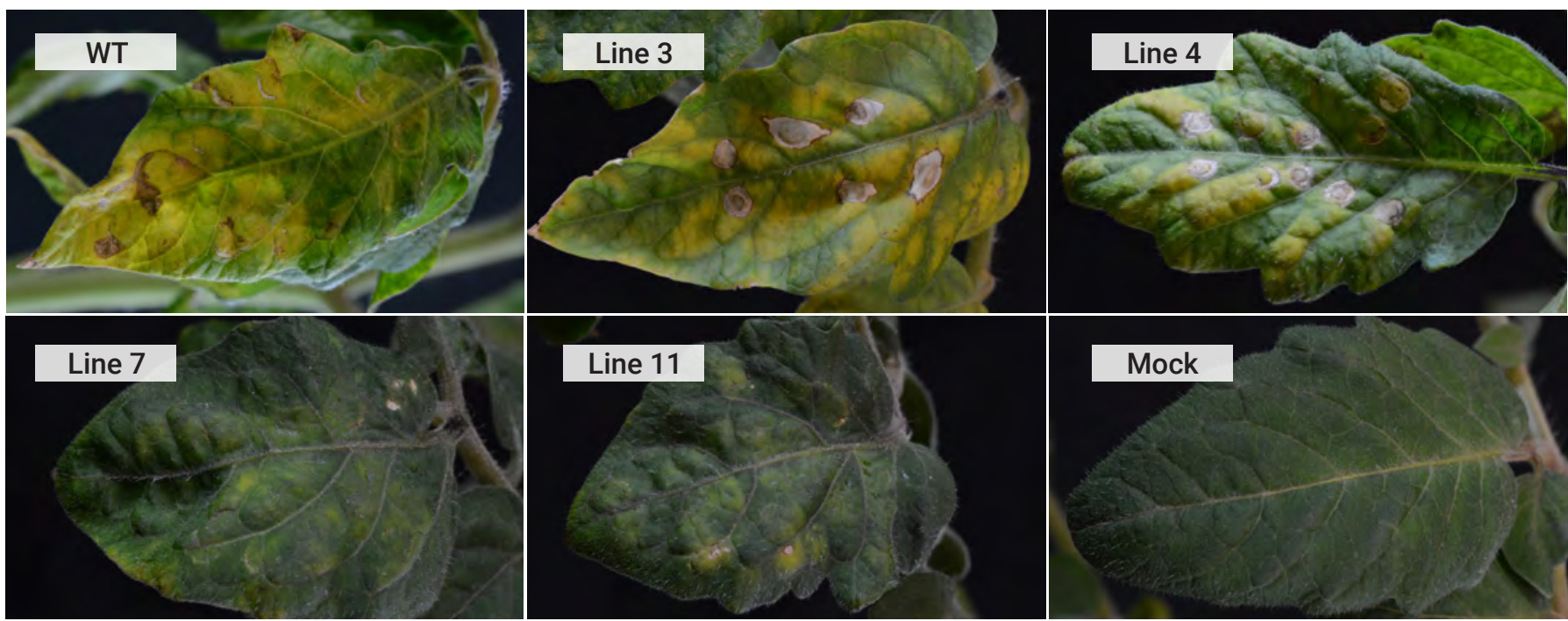

Figure 3. Transgenic expression of AtEFR, AtFLS2 and AtBAK1 in tomato confers resistance to $P$. syringae pv. syringae and $P$. syringae pv. tomato. (A) Colony forming units on the different $\mathrm{F}_{4}$ transgenic tomato lines and wild type (WT) plants after the bacterial infections. Results are average \pm s.e.m.; means with the same letters are not significantly different (Student $t$, $P \leq 0.05$ ). (B) Symptoms development on leafs of the different $F_{4}$ transgenic tomato lines and wild type (WT) plants at 10 d post-infection with $P$. syringae pv. tomato. Mock represents a control treatment with no bacteria. 
A)

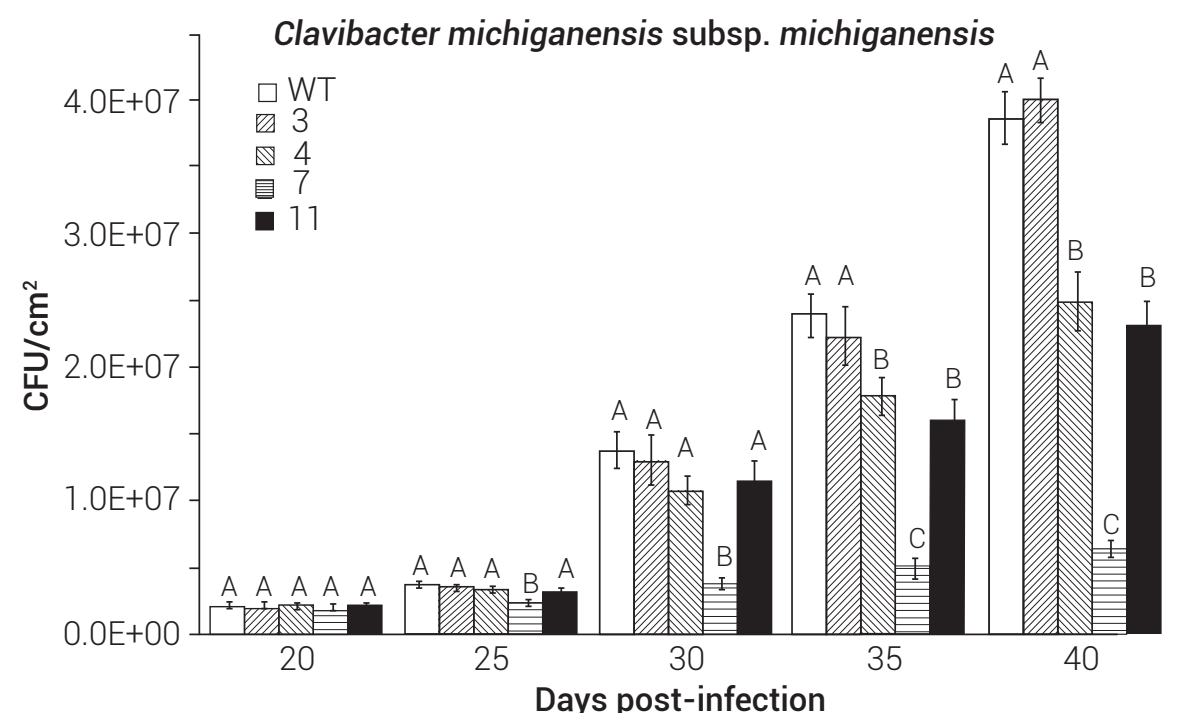

B)
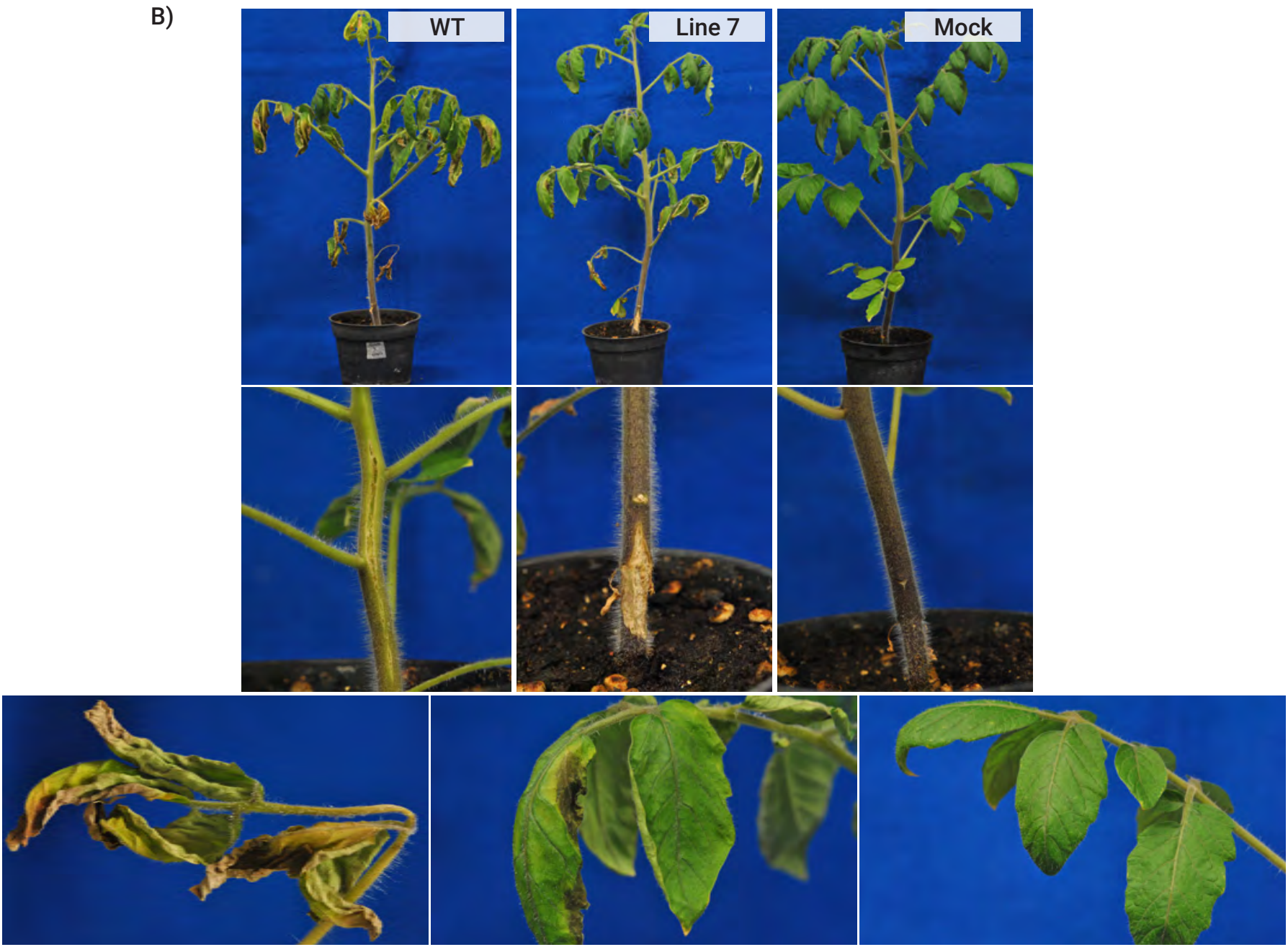

Figure 4. Transgenic expression of AtEFR, AtFLS2 and AtBAK1 in tomato confers resistance to C. michiganensis subsp. michiganensis. (A) Colony forming units on the different $\mathrm{F}_{4}$ transgenic tomato lines and wild type (WT) plants after the bacterial infections. Results are average \pm s.e.m.; means with the same letters are not significantly different (Student $t, P \leq 0.05)$. (B) Bacterial canker symptoms development on the $\mathrm{F}_{4}$ tomato and wild type (WT) plants at $35 \mathrm{~d}$ post-infection with $\mathrm{C}$. michiganensis subsp. michiganensis. Upper row: general view of the whole plant; middle row: close-up of the stem at the site of inoculation; bottom row: symptoms development on leaves. Mock represents a control treatment with no bacteria. 

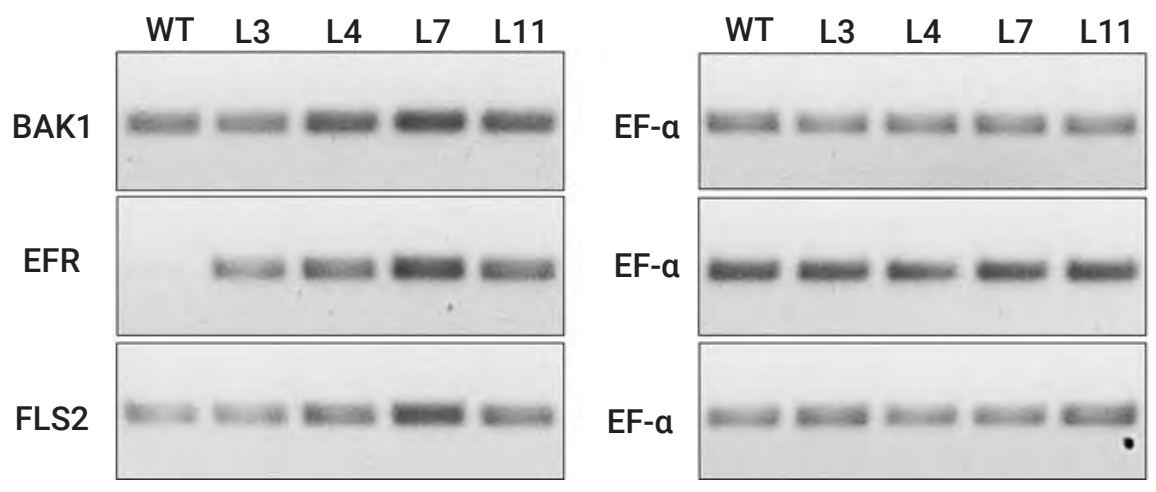

Figure 5. RT-PCR analysis of $p C A M B I A-E F R: U b: B A K 1: U b: F L S 2$ transgenic tomato lines using BAK1, EFR and FLS2 specific primers. A control RT-PCR of the house-keeping gene EF- $a$ indicates equal loading.

genes), Lines 4 and 11, but specially Line 7, showed higher transcript accumulation indicating an overexpression of those genes as a result of the heterologous expression of the Arabidopsis genes under a constitutive promoter.

Line 3 showed no higher transcript accumulation compared with the WT plants, thus explaining why plants from Line 3 showed little to none resistance to the bacterial infections. Nevertheless, Line 3 showed transcript accumulation of EFR (though only a little) indicating that plants from Line 3 were indeed transgenic but with no optimal expression of the transgenes. As it was expected, WT plants showed no transcript accumulation of EFR since that gene is restricted to Brassicaceae (Zipfel et al., 2006), while once again Line 7 showed the highest transcript accumulation, thus helping to explain why plants from such line had the lowest CFU counting and the mildest symptoms from the bacterial infections.

\section{CONCLUSIONS}

Tomato plants transformed with the specified construction are more resistant to infection by Pseudomonas syringae pv. syringae, P. syringae pv. tomato and Clavibacter michiganensis subsp. michiganensis than wild-type nontransformed plants. Whether the resistance generated by the heterologous expression of more than one gene related to plant innate immunity is stronger or more durable than that achieved by the expression of a single gene, it remains to be elucidated. This technology can potentially be applied to other important crops to confer resistance to a wide range of pathogenic bacteria.

\section{AKNOWLEDGMENTS}

We thank Dr. J. A. López-Buenfil (Senasica-Sagarpa) for providing cultures of $P$. syringae $\mathrm{pv}$. syringae B728a; J. P. Delano-Frier and L. P. Partida-Martínez (Cinvestav Irapua- to) for providing cultures of $P$. syringae pv. tomato DC300 and $C$. michiganensis subsp. michiganensis respectively; A. G. Vallejo-Vargas (Cinvestav Irapuato) for the help and advices on the transformation experiments; and S. de Folter (Langebio-Cinvestav Irapuato) for providing the cDNA from A. thaliana. M. Plancarte-De la Torre is supported by a grant from Mexico's Science and Technology National Council (Conacyt).

\section{REFERENCES}

Albert M., A. K. Jehle, M. Lipschis, K. Mueller, Y. Zeng and G. Felix (2010) Regulation of cell behaviour by plant receptor kinases: pattern recognition receptors as prototypical models. European Journal of Cell Biology 89:200-207.

Baulcombe D. (2005) RNA silencing. Trends in Biochemical Sciences 30:290-293.

Boller T. and G. Felix (2009) A renaissance of elicitors: perception of microbe-associated molecular patterns and danger signals by pattern-recognition receptors. Annual Review of Plant Biology 60:379-406.

Brown J. K. M., E. M. Foster and R. B. O'Hara (1997) Adaptation of powdery mildew populations to cereal varieties in relation to durable and non-durable resistance. In: The Gene-for-Gene Relationship in Plant-Parasite Interaction. I. R. Crute, E. B. Holub and J. J. Burdon (eds.). CAB International. UK. pp:119-138.

Cai R., J. Lewis, S. Yan, H. Liu, C. R. Clarke, F. Campanile, N. F. Almeida, D. J. Studholme, M. Lindeberg, D. Schneider, M. Zaccardelli, J. C. Setubal, N. P. Morales-Lizcano, A. Bernal, G. Coaker, C. Baker, C. L. Bender, S. Leman and B. A. Vinatzer (2011) The plant pathogen Pseudomonas syringae pv. tomato is genetically monomorphic and under strong selection to evade tomato immunity. PLOS Pathogens 7:e1002130. doi:10.1371/journal.ppat.1002130

Chinchilla D., Z. Bauer, M. Regenass, T. Boller and G. Felix (2006) The Arabidopsis receptor kinase FLS2 binds flg22 and determines the specificity of flagellin perception. The Plant Cell 18:465-476.

Chinchilla D., L. Shan, P. He, S. de Vries and B. Kemmerling (2009) One for all: the receptor-associated kinase BAK1. Trends in Plant Science 14:535-541.

Danna C. H., Y. A. Millet, T. Koller, S. W. Han, A. F. Bent, P. C. Ronald and F. M. Ausubel (2011) The Arabidopsis flagellin receptor FLS2 mediates the perception of Xanthomonas Ax21 secreted peptides. Proceedings of the National Academy of Sciences of the United States of America 108:9286-9291.

Eichenlaub R., K. H. Gartemann and A. Burger (2006) Clavibacter michiganensis, a group of gram-positive phytopathogenic bacteria: In: Plant-Associated Bacteria. S. S. Gnanamanickam (ed.). Springer. Dordrecht, The Netherlands. pp:385-421. 
Felix G., J. D. Duran, S. Volko and T. Boller (1999) Plants have a sensitive perception system for the most conserved domain of bacterial flagellin. The Plant Journal 18:265-276.

Fukuoka S., N. Saka, H. Koga, K. Ono, T. Shimizu, K. Ebana, N. Hayashi, A. Takahashi, H. Hirochika, K. Okuno and M. Yano (2009) Loss of function of a proline-containing protein confers durable disease resistance in rice. Science 325:998-1001.

He P., L. Shan, N. C. Lin, G. B. Martin, B. Kemmerling, T. Nürnberger and J. Sheen (2006) Specific bacterial suppressors of MAMP signaling upstream of MAPKKK in Arabidopsis innate immunity. Cell 125:563-575.

He K., S. Xu and J. Li (2013) BAK1 directly regulates brassinosteroid perception and BRI1 activation. Journal of Integrative Plant Biology 55:1264-1270

Höfte M. and P. De Vos (2006) Plant pathogenic Pseudomonas species.In: Plant-Associated Bacteria. S. S. Gnanamanickam (ed.). Springer. Dordrecht, The Netherlands. pp:507-533.

Katagiri F., R. Thilmony and S. Y. He (2002) The Arabidopsis thaliana-Pseudomonas syringae Interaction. The Arabidopsis Book. American Society of Plant Biologists 1:e0039. doi:10.1199/tab.0039

Kim K. Y., M. S. Shin, W. J. Kim, Y. J. Mo, J. K. Nam, T. H. Noh, B. K. Kim and J. K. Ko (2009) Effective combination of resistance genes against rice bacterial blight pathogen. Korean Journal of Breeding Science 41:244-251.

Kumar J. R. and S. Nayak (2010) Gene pyramiding- A broad spectrum technique for developing durable stress resistance in crops. Biotechnology and Molecular Biology Review 5:51-60.

Kunze G., C. Zipfel, S. Robatzek, K. Niehaus, T. Boller and G. Felix (2004) The $\mathrm{N}$ terminus of bacterial elongation factor Tu elicits innate immunity in Arabidopsis plants. The Plant Cell 16:3496-3507.

Lacombe S., A. Rougon-Cardoso, E. Sherwood, N. Peeters, D. Dahlbeck, H. P. van Esse, M. Smoker, G. Rallapalli, B. P. H. J. Thomma, B. Staskawicz, J. D. G. Jones and C. Zipfel (2010) Interfamily transfer of a plant pattern-recognition receptor confers broad-spectrum bacterial resistance. Nature Biotechnology 28:365-369.

Louws F. J., J. Bell, C. M. Medina-Mora, C. D. Smart, D. Opgenorth, C. A. Ishimaru, M. K. Hausbeck, F. J. de Bruijn and D. W. Fulbright (1998) rep-PCR-mediated genomic fingerprinting: a rapid and effective method to identify Clavibacter michiganensis. Phytopathology 88:862-868

Nguyen H. P., S. Chakravarthy, A. C. Velásquez, H. L. McLane, L. Zeng, H. Nakayashiki, D. H. Park, A. Collmer and G. B. Martin (2010) Methods to study PAMP-triggered immunity using tomato and Nicotiana benthamiana. Molecular Plant-Microbe Interactions 23:991-999.

Peng H. C. and I. Kaloshian (2014) The tomato leucine-rich repeat receptor-like kinases SISERK3A and SISERK3B have overlapping functions in bacterial and nematode innate immunity. PLOS ONE 9: e93302. doi:10.1371/journal.pone.0093302.

Peña-Ramírez Y. J., E. Tasciotti, A. Gutiérrez-Ortega, A. J. Donayre-Torres, M. T.
Olivera Flores, M. Giacca and M. A. Gómez Lim (2007) Fruit-specific expression of the human immunodeficiency virus type 1 Tat gene in tomato plants and its immunogenic potential in mice. Clinical and Vaccine Immunology 14:685-692.

Robatzek S., P. Bittel, D. Chinchilla, P. Köchner, G. Felix, S. H. Shiu and T. Boller (2007) Molecular identification and characterization of the tomato flagellin receptor LeFLS2, an orthologue of Arabidopsis FLS2 exhibiting characteristically different perception specificities. Plant Molecular Biology 64:539-547.

Shan L., P. He, J. Li, A. Heese, S. C. Peck, T. Nürnberger, G. B. Martin and J. Sheen (2008) Bacterial effectors target the common signaling partner BAK1 to disrupt multiple MAMP receptor-signaling complexes and impede plant immunity. Cell Host \& Microbe 4:17-27.

Suh J. P., J. U. Jeung, T. H. Noh, Y. C. Cho, S. H. Park, H. S. Park, M. S. Shin, C. K. Kim and K. K. Jena (2013) Development of breeding lines with three pyramided resistance genes that confer broad-spectrum bacterial blight resistance and their molecular analysis in rice. Rice 6:5.

Suh J. P., T. H. Noh, K. Y. Kim, J. J. Kim, Y.-G. Kim and K. K. Jena (2009) Expression levels of three bacterial blight resistance genes against K3a race of Korea by molecular and phenotype analysis in japonica rice (O. sativa L.). Journal of Crop Science and Biotechnology 12:103-108.

Sun Y., L. Li, A. P. Macho, Z. Han, Z. Hu, C. Zipfel, J. M. Zhou and J. Chai (2013) Structural basis for flg22-induced activation of the Arabidopsis FLS2-BAK1 immune complex. Science 342:624-628.

Tago D., H. Andersson and N. Treich (2014) Pesticides and health: a review of evidence on health effects, valuation of risks, and benefitcost analysis. Advances in Health Economics and Health Services Research 24:203-295.

Walker J. M. and R. D. Vierstra (2007) A ubiquitin-based vector for the co-ordinated synthesis of multiple proteins in plants. Plant Biotechnology Journal 5:413-421.

Walters M. (2015) The plant innate immune system. Journal of Endocytobiosis and Cell Research 26:8-12.

Wilkinson K. D. (2000) Ubiquitination and deubiqutination targeting of proteins for degradations by the proteasome. Seminars in Cell and Developmental Biology 11:141-148.

Wulff B. B. H., D. M. Horvath and E. R. Ward (2011) Improving immunity in crops: new tactics in an old game. Current Opinion in Plant Biology 14:468-476.

Zhao Y., R. Thilmony, C. L. Bender, A. Schaller, S. Y. He and G. A. Howe (2003) Virulence systems of Pseudomonas syringae pv. tomato promote bacterial speck disease in tomato by targeting the jasmonate signaling pathway. The Plant Journal 36:485-499.

Zipfel C., G. Kunze, D. Chinchilla, A. Caniard, J. D. G. Jones, T. Boller and G. Felix (2006) Perception of the bacterial PAMP EF-Tu by the receptor EFR restricts Agrobacterium-mediated transformation. Cell 125:749-760. 